\title{
Chlorophyll fluorescence emission and its relation to skin color and firmness during ripening of guava fruit
}

\author{
Ilana Urbano Bron ${ }^{a}$, Rafael Vasconcelos RIBEIRO ${ }^{b *}$, Marisa AZZOLINI ${ }^{c}$, Eduardo Caruso MACHADO ${ }^{b}$, Angelo Pedro JACOMINO ${ }^{d}$
}

a Centro APTA de Engenharia

e Automação, Instituto

Agronòmica CP 26,

13201-970, Jundiaí SP, Brazil

b Centro de Pesquisa

e Desenvolvimento

em Ecofisiologia e Biofísica,

Instituto Agronômico, CP 28, 13001-970, Campinas SP,

Brazil

rafael@iac.sp.gov.br

c Departamento de Botânica, Universidade Federal do Rio Grande do Sul, 91501-970,

Porto Alegre RS, Brazil

d Departamento de Produção Vegetal, Escola Superior de Agricultura "Luiz de Queiroz", Universidade de São Paulo, CP 09, 13418-900, Piracicaba SP, Brazil

${ }^{*}$ Correspondence and reprints

Received 23 March 2004 Accepted 23 August 2004

Fruits, 2005, vol. 60, p. 25-32 (C) 2005 Cirad/EDP Sciences All rights reserved

DOI: 10.1051/fruits:2005009

RESUMEN EsPaÑoL, p. 32

\section{Chlorophyll fluorescence emission and its relation to skin color and firmness during ripening of guava fruit.}

Abstract - Introduction. Chlorophyll fluorescence (chl-fluorescence) has been used in postharvest studies as a non-destructive technique for evaluating fruit ripening. Since there are no available studies using chl-fluorescence in guava fruit, the aim of this work was to verify the relations between chl-fluorescence parameters and fruit quality attributes, such as skin color and fruit firmness, and to measure the chl-fluorescence during ripening of guava fruit. Materials and methods. Firstly, maximal $\left(\mathrm{F}_{\mathrm{m}}\right)$, minimal $\left(\mathrm{F}_{\mathrm{o}}\right)$, variable $\left(\mathrm{F}_{\mathrm{v}}\right)$, and variable to maximal $\left[\mathrm{F}_{\mathrm{v}} / \mathrm{F}_{\mathrm{m}}\right]$ fluorescence yields, skin color $\left(\mathrm{H}^{\circ}\right)$ and fruit firmness were evaluated in guava fruit harvested at three ripeness stages: dark-green (I), light-green (II) and yellowish-green (III). Secondly, changes in the above chl-fluorescence parameters and $\mathrm{H}^{\circ}$ were measured during 7 days of ripening. Relations between the evaluated parameters were also studied. Results and discussion. The three ripeness stages were well segregated using the $\mathrm{H}^{\circ}, \mathrm{F}_{\mathrm{m}}$ and fruit firmness parameters. $\mathrm{F}_{\mathrm{o}}$ was insensible to early changes in fruit ripening, maintaining relatively stable values until fruit firmness of $20 \mathrm{~N}$. When considering changes in chl-fluorescence and $\mathrm{H}^{\circ}$ during ripening, there were no significant differences between guava fruit harvested at stages II or III. The $\left[\mathrm{F}_{\mathrm{v}} / \mathrm{F}_{\mathrm{m}}\right]$ value decline was only evident on the fifth day of ripening, whereas $\mathrm{F}_{\mathrm{v}}, \mathrm{F}_{\mathrm{m}}$ and $\mathrm{H}^{\circ}$ began to decrease on the first day. Regardless of $\left[\mathrm{F}_{\mathrm{v}} / \mathrm{F}_{\mathrm{m}}\right]$, the relations between chl-fluorescence parameters and $\mathrm{H}^{\circ}$ tended to increase from ripeness stages I to III, with $\mathrm{F}_{\mathrm{m}}$ having the highest correlation with $\mathrm{H}^{\circ}$. The results show that chl-fluorescence can be used to evaluate the ripening and senescence of guava fruit, with $\mathrm{F}_{\mathrm{m}}$ being a good ripening indicator.

Brazil / Psidium guajava / fruit / ripening / non-destructive methods / chlorophylls / fluorescence/ firmness / coloration

Fluorescence émise par la chlorophylle en relation avec la couleur de peau et la fermeté du fruit pendant la maturation de la goyave.

Résumé - Introduction. La fluorescence de la chlorophylle (fluorescence-chl) a été utilisée dans des études après-récoltes comme technique non destructive pour évaluer la maturation du fruit. De telles études utilisant la fluorescence-chl chez la goyave n'existant pas, nous avons cherché à vérifier les relations liant la fluorescence-chl et certains paramètres de qualité du fruit, telles que la couleur de peau et la fermeté de fruit, et à mesurer la fluorescence-chl pendant la maturation de la goyave. Matériel et méthodes. Les rendements de la fluorescence maximale $\left(\mathrm{F}_{\mathrm{m}}\right)$, minimale $\left(\mathrm{F}_{\mathrm{O}}\right)$ et variable $\left(\mathrm{F}_{\mathrm{v}}\right)$, et le rapport $\left[\mathrm{F}_{\mathrm{v}} / \mathrm{F}_{\mathrm{m}}\right]$, la couleur de la peau $\left(\mathrm{H}^{\circ}\right)$ et la fermeté de fruit ont été tout d'abord évalués sur des goyaves récoltées à trois stades de maturité : (I) vert foncé, (II) vert clair et (III) vert jaunâtre. Dans un second temps, les changements de ces derniers paramètres de fluorescence-chl et de $\mathrm{H}^{\circ}$ ont été mesurés pendant 7 jours de maturation. Les relations entre les paramètres évalués ont été également étudiées. Résultats et discussion. Les trois stades de maturité ont été bien discriminés en utilisant les paramètres $\mathrm{H}^{\circ}, \mathrm{F}_{\mathrm{m}}$ et la fermeté de fruit. $\mathrm{F}_{\mathrm{O}}$ a été insensible aux premiers changements de la maturation du fruit, maintenant des valeurs relativement stables jusqu'à ce que la fermeté du fruit atteigne $20 \mathrm{~N}$. Aucune différence significative de fluorescence-chl et de $\mathrm{H}^{\circ}$ n'a été constatée entre les goyaves récoltées aux stades II ou III. Le déclin de la valeur $\left[\mathrm{F}_{\mathrm{v}} / \mathrm{F}_{\mathrm{m}}\right]$ n'a été évident que le cinquième jour de la maturation, tandis que les paramètres $\mathrm{F}_{\mathrm{v}}, \mathrm{F}_{\mathrm{m}}$ et $\mathrm{H}^{\mathrm{o}}$ ont commencé à diminuer dès le premier jour. Indépendamment du rapport $\left[\mathrm{F}_{\mathrm{v}} / \mathrm{F}_{\mathrm{m}}\right]$, les relations entre les paramètres de fluorescence-chl et $\mathrm{H}^{\circ}$ ont eu tendance à augmenter du stade de maturité I au stade III, $\mathrm{F}_{\mathrm{m}}$ ayant la plus forte corrélation avec $\mathrm{H}^{\circ}$. Les résultats montrent que la fluorescence-chl peut être employée pour évaluer la maturation et la sénescence de la goyave, le paramètre $\mathrm{F}_{\mathrm{m}}$ étant un bon indicateur de maturation.

Brésil / Psidium guajava / fruit / mûrissage / méthode non destructive / chlorophylle / fluorescence / fermeté / coloration 


\section{Introduction}

In recent years, postharvest studies have been attracting the interest of industry and research institutions, due to their potential application in increasing the shelf life of fresh produce and reducing losses. Therefore, the availability of information about the physiology and biochemistry of ripening is essential to increase the shelf life and quality of many products.

Among the alterations during fruit ripening, fruit firmness, skin color, flavor and texture are the most affected characteristics [1]. Skin color and fruit firmness have been used as helpful features to characterize or segregate fruit from different ripeness stages. It is known that skin color is well correlated with fruit firmness, but this correlation may be lost at specific stages [2], as verified in papaya fruit by Bron et al. [3]. An erroneous evaluation of the fruit ripeness stage by packing lines may lead to an irregular ripening within the same fruit lot. Fruit classification can be improved by high-speed and non-destructive measurements, as well as a combination of techniques [2], such as colorimetry and fluorometry [3]. An evaluation method that considers both internal and external fruit attributes could be used to classify fruit on packing lines and improve fruit quality for final consumers [4].

Among the techniques available for postharvest studies, chlorophyll fluorescence has been studied as a helpful tool to evaluate the ripening and senescence of green tissues, being used in both green leaves and several chlorophyll-containing fruits [3-7]. Chlorophyll fluorescence has been used to evaluate injuries caused by low temperature storage [8], physiological disorders related to low oxygen and high carbon dioxide damage [9], and storage effects [10-11]. Chlorophyll fluorescence emission at room temperature is almost exclusively originated from light-excited chlorophyll $a$ molecules associated with photosystem II (PSII), reflecting the primary photosynthetic reactions in the thylakoid membranes [12]. For excited chlorophyll molecules to return to the ground level (de-excited), one or more of the following mechanisms is necessary: fluorescence emission, excitation transference to neighboring molecules, photochemical reaction and/or thermal dissipation [13-15].

Therefore, fluorescence is a small portion of absorbed energy re-irradiated and not used in the photosynthetic process [13, 16].

In ripe or senescent fruit, chlorophyll fluorescence is influenced by reductions in chlorophyll content and chlorophyllase activity [1, 8, 17]. Smillie et al. [8] reported that the decline in chlorophyll fluorescence during the ripening of banana and mango was associated with loss of chlorophyll content and chloroplast competence. A common feature accompanying senescence is the increase in cell membrane degradation [18], which leads to chloroplast senescence, a process where membranes lose their physical integrity, limiting the photosynthetic capacity and, consequently, changing the fluorescence parameters [19].

When compared with other tropical fruits, guava fruit stands out for its excellent nutritional quality, as one of the most complete and balanced fruits [20]. Guava fruit has a strong tendency for increased consumption, which sometimes is impaired by inadequate postharvest techniques or handling. Since there are no available studies involving the use of the chlorophyll fluorescence technique in this fruit, the present work had the following goals:

- to verify the relations between chlorophyll fluorescence parameters and fruit quality attributes, such as skin color and fruit firmness,

- to measure the chlorophyll fluorescence changes during the ripening of guava fruit.

\section{Materials and methods}

\subsection{Plant material}

'Pedro Sato' guava (Psidium guajava L.) fruits were harvested from a commercial orchard in Vista Alegre County, SP Brazil, in August 2002 and transported by refrigerated truck at $15^{\circ} \mathrm{C}$ for $4 \mathrm{~h}$ to Piracicaba, SP, Brazil, where each fruit was grouped according to its size and visual skin color. 


\subsection{Chlorophyll fluorescence measurements}

A pulse amplitude-modulated fluorometer (FMS1, Hansatech, King's Lynn, UK) was used to assess the minimal $\left(\mathrm{F}_{\mathrm{O}}\right)$ and maximal $\left(\mathrm{F}_{\mathrm{m}}\right)$ chlorophyll fluorescence, variable chlorophyll fluorescence $\left(\mathrm{F}_{\mathrm{v}}=\mathrm{F}_{\mathrm{m}}-\mathrm{F}_{\mathrm{O}}\right)$, and potential quantum yield of photosystem II, given by the relation $\left[\mathrm{F}_{\mathrm{v}} / \mathrm{F}_{\mathrm{m}}\right]$ [21]. The $\mathrm{F}_{\mathrm{O}}$ parameter reflects the fluorescence yield when PSII is able to pass on almost all of the electrons excited by light. The fluorescence intensity at a maximum level is referred to as $\mathrm{F}_{\mathrm{m}}$ and PSII is able to pass on only a fraction of the electrons excited by light. The $\left[\mathrm{F}_{\mathrm{v}} / \mathrm{F}_{\mathrm{m}}\right]$ value is a measurement of the efficiency of the energy transfer process and chloroplast activity [21]. Before chlorophyll fluorescence measurements, fruits were dark-adapted for 30 min using a dark towel. The fiber optic was fitted with a fiber-optic adapter to fix the distance between the fiberoptic terminus and the fruit exocarp. $\mathrm{F}_{\mathrm{O}}$ was measured with a measuring beam at a light intensity less than $0.05 \mu \mathrm{mol} \cdot \mathrm{m}^{-2} \cdot \mathrm{s}^{-1}$. $\mathrm{F}_{\mathrm{m}}$ was obtained by measuring chlorophyll fluorescence during a $0.7-s$ pulse of saturating light $\left(18000 \mu \mathrm{mol} \cdot \mathrm{m}^{-2} \cdot \mathrm{s}^{-1}\right)$. Measurements were taken on two opposite positions of each fruit half and averaged. To ensure that subsequent measurements were taken at the same location on the fruit surface, each guava fruit was numbered and a circular mark was made on each fruit half, using a marker pen. Measurements of fruit firmness and skin color were taken at the same marked location.

\subsection{Pulp firmness and skin color measurements}

The firmness of each fruit was measured using a digital penetrometer (53200-Samar, Tr-Turoni, Forli, Italy) fitted with an 8-mm diameter probe. One skin disc was removed with a peeler at the previously marked position (the same position where the chlorophyll fluorescence and skin color measurements were taken). Readings on firmness were recorded in Newtons $(\mathrm{N})$ and skin color was measured as hue angle $\left(\mathrm{H}^{\circ}\right)$ with a colorimeter (Minolta chromameter 300, Minolta camera Co., Osaka, Japan).

\subsection{Relations between chlorophyll fluorescence parameters and fruit quality attributes}

We used fruit sorted into three different ripeness stages based on visual skin color [22]: dark-green (stage I), light-green (stage II) and yellowish-green (stage III). Nine fruits of each ripeness stage were used to evaluate chlorophyll fluorescence, fruit firmness and skin color, as well as to assess the relations between these parameters.

\subsection{Changes in chlorophyll fluorescence and skin color during fruit ripening}

Five guava fruits harvested at the three maturity stages were maintained at room conditions, to simulate commercial conditioning, where air temperature $\left[(24 \pm 1){ }^{\circ} \mathrm{C}\right]$ and relative humidity $[(80 \pm 4) \%]$ were monitored. Changes in chlorophyll fluorescence and skin color were measured during the ripening at 24-h intervals for 7 days. Each fruit was numbered and all measurements were taken at the same marked surface point on each fruit half to ensure that subsequent readings would be taken from the same tissues.

\subsection{Data analyses}

The experimental design was completely randomized with replications varying according to the experiment: nine for the study of relations between chlorophyll fluorescence parameters and fruit quality attributes, and five for the experiment on changes in chlorophyll fluorescence and skin color during fruit ripening. Data were analyzed using the ANOVA procedure and the Tukey test $(p<$ 0.05 ) to compare means (ESTAT, version 2.0, UNESP-FCAV, Jaboticabal, SP, Brazil). In addition, the relations between fruit firmness, skin color and chlorophyll fluorescence parameters $\left(\mathrm{F}_{\mathrm{O}}, \mathrm{F}_{\mathrm{m}}, \mathrm{F}_{\mathrm{v}}\right.$ and $\left.\mathrm{F}_{\mathrm{v}} / \mathrm{F}_{\mathrm{m}}\right)$ were tested for significance using correlation analyses (Origin, version 6.0, Microcal software, Northampton, MA, USA). 


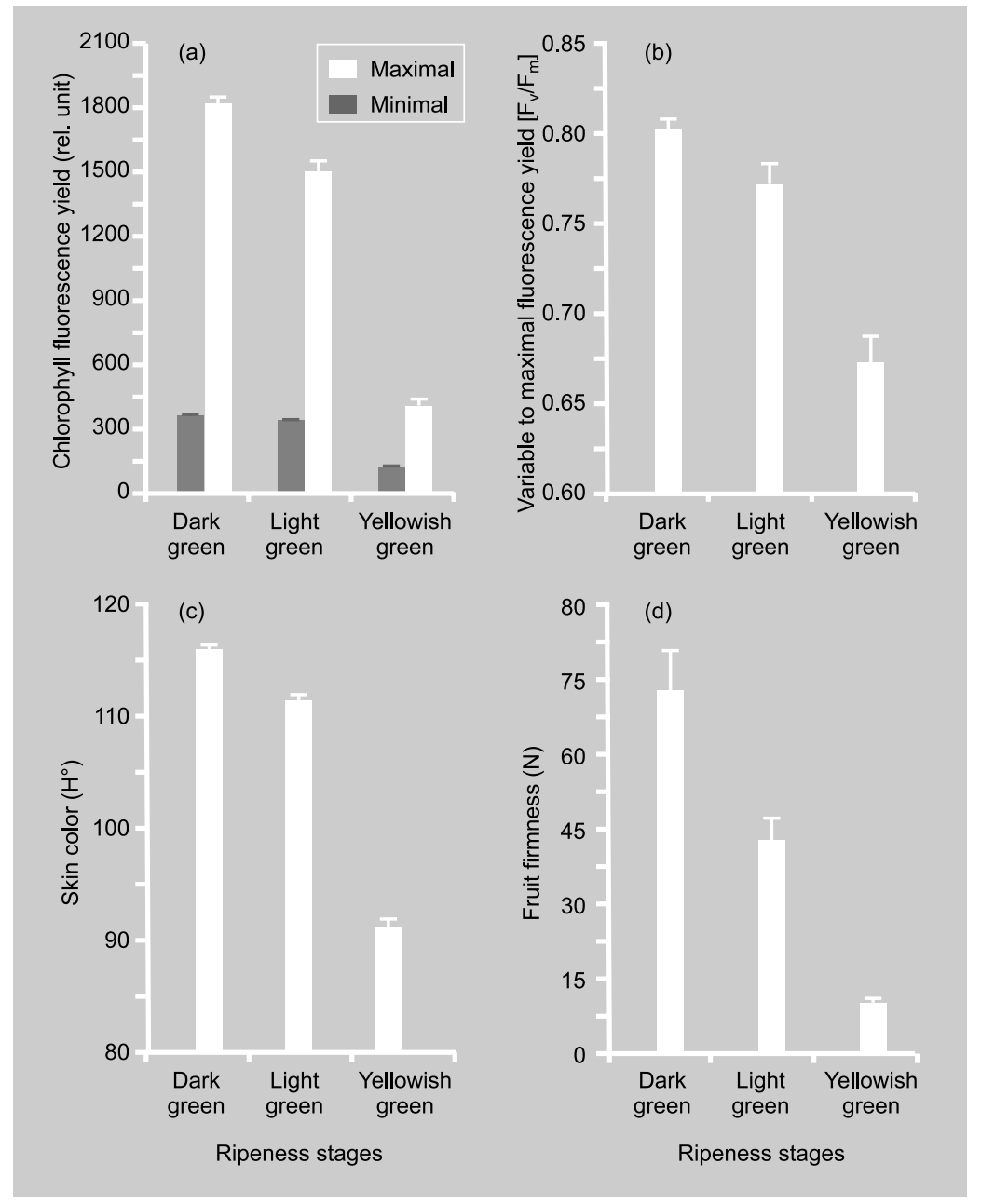

Figure 1.

Minimal and maximal chlorophyll fluorescence yields (a), variable to maximal chlorophyll fluorescence yield (b), skin color (c) and fruit firmness (d) measured at three ripeness stages of guava fruit: dark-green, light-green and yellowish-green. Bars represent the mean value of nine replications (+ standard error).

\section{Results and discussion}

\subsection{Relations between chlorophyll fluorescence parameters and fruit quality attributes}

As expected, the chlorophyll fluorescence parameters, as well as skin color and fruit firmness, decreased with advanced ripeness $(p<0.05)$ (figure 1). The ripeness stages were well segregated using $\mathrm{F}_{\mathrm{m}}$ and skin color (figures 1a, 1c). Although firmness also differentiated $(p<0.05)$ the three ripeness stages (figure $1 d$ ), this parameter had the highest coefficient of variation (38.9\%). Several factors, such as fruit wilting and moisture loss, could hinder the correct evaluation of fruit firmness. In addition, firmness changes during fruit ripening are the result of various enzymatic activities [23], which are controlled by physiological and environmental factors.

In general, skin color changes during fruit ripening result from greenness loss due to chlorophyll degradation [1]. Chlorophyll degradation is a complex process in which, after successive removal of phytol and $\mathrm{Mg}^{2+}$ from the chlorophyll molecule by chlorophyllase and 'Mg dechelatase', the pheophorbide $a$ is cleaved and reduced to yield a colorless compound [24].

Therefore, one probable cause of chlorophyll fluorescence decline could be a decrease in chlorophyll content associated with fruit ripening, as reported in papaya by Sanxter et al. [17]. However, it could also be due to membrane degradation during ripening [18]. The drop in $\left[\mathrm{F}_{\mathrm{v}} / \mathrm{F}_{\mathrm{m}}\right], \mathrm{F}_{\mathrm{O}}$ and $\mathrm{F}_{\mathrm{v}}$ also reflect a loss in chloroplast function with advanced fruit ripening and senescence [5]. Decreases in $F_{m}$ indicate an increase in heat formation in both the reaction center and antenna of PSII [15], whereas changes in $\mathrm{F}_{\mathrm{O}}$ are due to structural alterations in the thylakoid membranes [25]. The fact that $\mathrm{F}_{\mathrm{O}}$ did not segregate the dark-green and light-green ripeness stages (figure 1a) suggests that guava fruit harvested at these stages did not exhibit differences in chloroplast membrane integrity, but only in chlorophyll content, which influenced the $\mathrm{F}_{\mathrm{m}}$ parameter.

Fruit firmness exhibited an exponential relationship with the skin color $\left(\mathrm{H}^{\circ}\right)$ and the chlorophyll fluorescence parameters (figure 2), with $\mathrm{F}_{\mathrm{m}}$ and $\mathrm{H}^{\mathrm{O}}$ having the highest correlation with fruit firmness (figures $2 a, 2 b$ ). Azzolini et al. [22] have also reported high correlations between skin color and fruit firmness in 'Pedro Sato' guavas.

Physiological processes during ripening generally occur in a predictable pattern. For this reason, skin color measurements usually give us an idea of pulp firmness. However, growing conditions or postharvest treatments may decouple physiological processes; it is thus important to evaluate the information about fruit quality by indirect measurements [2]. In addition, each measuring instrument evaluates a specific quality attribute, which suggests that combined parameters, assessing different characteristics, can be 
interesting for a more precise quality evaluation (figure 2).

The fluorescence parameter $\mathrm{F}_{\mathrm{O}}$ was relatively stable in fruits with firmness from (120 to 20) $\mathrm{N}$, whereas $\mathrm{F}_{\mathrm{m}}, \mathrm{F}_{\mathrm{v}},\left[\mathrm{F}_{\mathrm{v}} / \mathrm{F}_{\mathrm{m}}\right]$ and $\mathrm{H}^{\mathrm{O}}$ began to decrease in those with $40 \mathrm{~N}$ (figure 2). The decrease in chlorophyll fluorescence associated with fruit firmness loss has been reported during the ripening of other fruits, such as papaya [3] and apple [4], where $F_{m}$ was the parameter that showed the best correlation with fruit firmness. The decrease in $\mathrm{F}_{\mathrm{O}}$ only at firmness values around $20 \mathrm{~N}$ (figure $2 b$ ) could indicate that the chloroplast structure remained stable until those values of firmness, which could explain why fruits harvested at the dark-green and lightgreen ripeness stages were not segregated by using the $\mathrm{F}_{\mathrm{O}}$ parameter.

\subsection{Changes in chlorophyll fluorescence and skin color during fruit ripening}

In a broad sense, all evaluated parameters decreased with advanced ripening, and changes in chlorophyll fluorescence parameters followed the skin color tendencies ( $f$ igures 3, 4). Similar responses have also been detected during the ripening of apple [4], mango and banana [8], and papaya [3] fruits.

It is known that the ripening and senescence processes produce destabilization and loss of functionality of membranes via chemical and biophysical changes in lipids and/or proteins [18] and since protein-chlorophyll complexes are associated with thylakoid membranes, chlorophyll fluorescence may be an intrinsic indicator of the fluidity, stability and organization of membranes [12]. In fact, the fluorescence characteristics are altered when PSII is damaged by some kind of environmental stress or affected by physiological changes, supporting the use of chlorophyll fluorescence as an indirect measurement of the physiological status of green tissues [12, 13, 16, 26]. During apple ripening, chlorophyll fluorescence decline correlated well with fruit firmness and hue angle, appearing to reflect some loss of chloroplast function with advancing senescence [5].

The chlorophyll fluorescence and skin color changes were similar $(p>0.05)$ at the

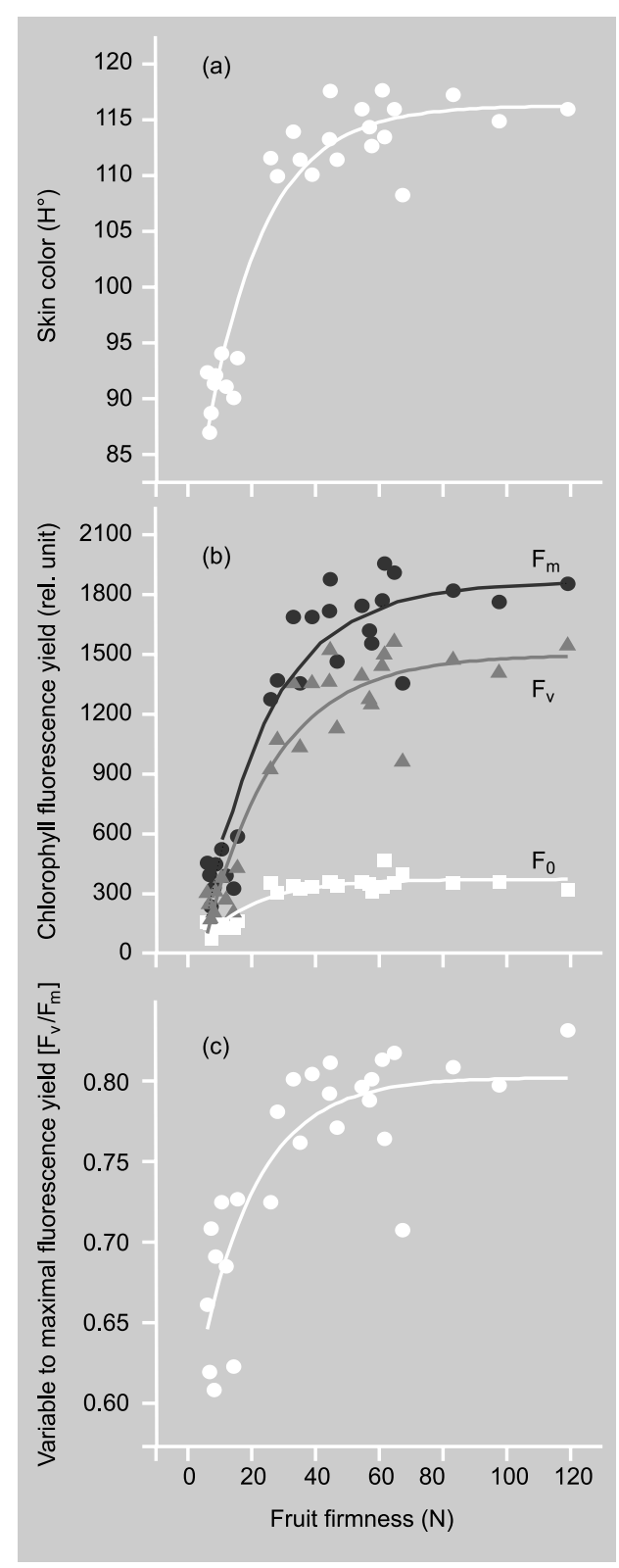

Figure 2.

Empirical correlations between skin color $\left(\mathrm{H}^{\circ}\right)$, chlorophyll fluorescence parameters $\left(F_{o}\right.$, $F_{m}, F_{v}$ and $\left.F_{v} / F_{m}\right)$ and fruit firmness (FF) in guava fruit $(n=27)$ held at room conditions $\left[(24 \pm 1)^{\circ} \mathrm{C}\right.$ and relative humidity of $(80 \pm 4) \%]$. Points represent measurements taken at three ripeness stages.

(a) $\mathrm{H}^{\circ}=116.3591$

$-41.2636 \mathrm{e}^{(-\mathrm{FF} / 18.1749)}$, $r^{2}=0.910$;

(b) $\mathrm{F}_{\mathrm{m}}=1874.2404$ $-2253.7914 \mathrm{e}^{(-\mathrm{FF} / 21.1122)}$ $r^{2}=0.911$; $F_{v}=1505.0801$ $-1860.4874 \mathrm{e}^{(-\mathrm{FF} / 21.8661)}$ $r^{2}=0.899 ;$

$\mathrm{F}_{0}=371.6968$

$-399.5267 \mathrm{e}^{(-\mathrm{FF} / 17.5701)}$ $r^{2}=0.860$;

(c) $\left[F_{v} / F_{m}\right]=0.8021$ $-0.2182 e^{(-F F / 17.8617)}$, $r^{2}=0.723$. light-green and yellowish-green ripeness stages when considering the ripening evolution (figures 3, 4). $\left[\mathrm{F}_{\mathrm{v}} / \mathrm{F}_{\mathrm{m}}\right]$ remained constant until the fifth day in fruit harvested at the dark-green stage (figure $3 d$ ). Bron et al. [3] also observed stable $\left[\mathrm{F}_{\mathrm{v}} / \mathrm{F}_{\mathrm{m}}\right]$ values until the fourth day of ripening in papaya fruit, which led these authors to suggest that this parameter was insensible to early changes in the ripening process. Accordingly, Sanxter et al. [17] reported that $\left[\mathrm{F}_{\mathrm{v}} / \mathrm{F}_{\mathrm{m}}\right]$ 


\section{I.U. Bron et al.}

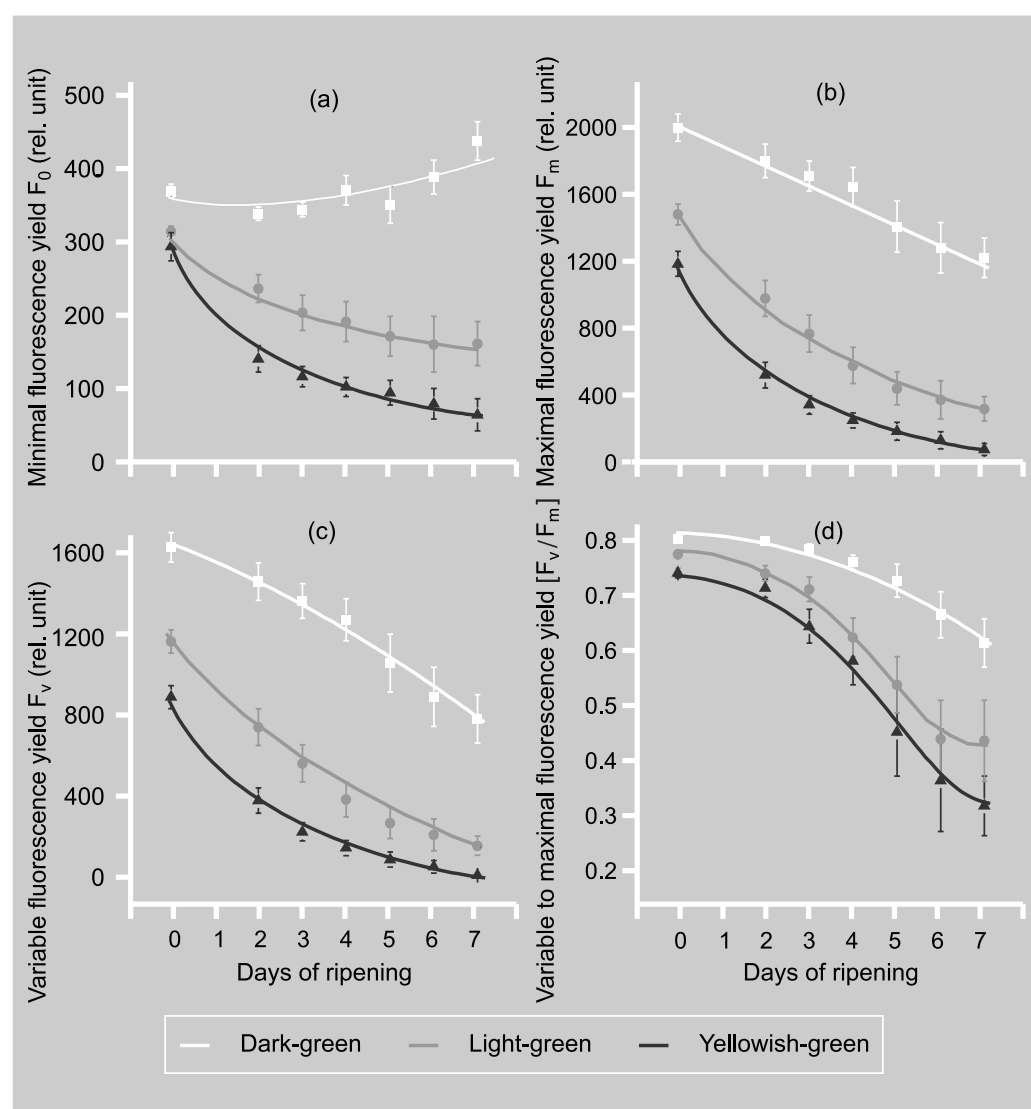

Figure 3.

Changes in minimal (a), maximal (b), variable (c), and variable to maximal (d) chlorophyll fluorescence yield during the ripening of guava fruit harvested at three ripeness stages: dark-green, light-green and yellowish-green. Guava fruits were held at room conditions $\left[(24 \pm 1){ }^{\circ} \mathrm{C}\right.$ and relative humidity of $(80 \pm 4) \%$ ]. Points represent the mean value of five replications ( \pm standard error).

\section{Figure 4.}

Changes in skin color during the ripening of guava fruit harvested at three ripeness stages: dark-green, light-green and yellowish-green. Guava fruits were held at room conditions

$\left[(24 \pm 1)^{\circ} \mathrm{C}\right.$ and relative humidity of $(80 \pm 4) \%]$. Points represent the mean value of five replications ( \pm standard error). values were relatively stable in papaya fruit from dead-green to three-quarter ripe. When fruits harvested at the dark-green ripeness stage were evaluated in this study, $\mathrm{F}_{\mathrm{O}}$ did not decrease during the ripening period ( $f$ igure $3 a$ ). At the seventh day of ripening, fruits harvested at this stage I were still unripe, which was confirmed by $\mathrm{H}^{\circ}$ values (figure 4) and probably caused by no changes in chlo-

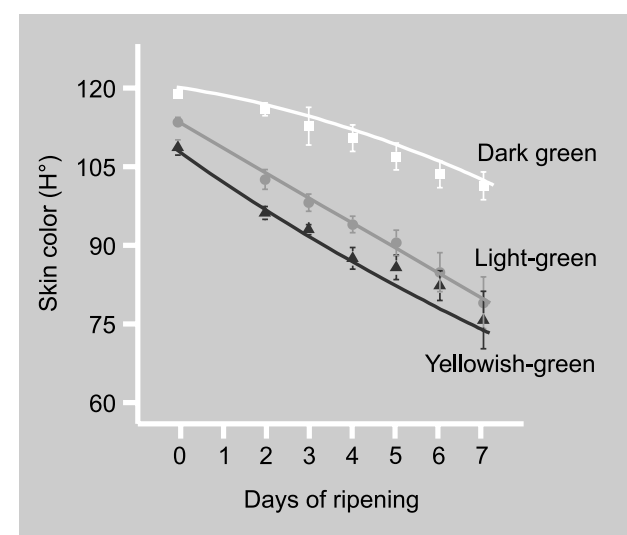

roplast membrane integrity. Therefore, changes in chlorophyll fluorescence parameters during the ripening period tend to be sensitive to the ripeness stage at which guava fruits are harvested.

The relations between skin color and chlorophyll fluorescence parameters were also influenced by the ripeness stages at harvest time (figure 5). Some studies have shown that sample size, cultivars, tissue age [27] and environmental conditions during ripening [4] can affect the relation between chlorophyll fluorescence emission and fruit quality characteristics.

The highest correlations were found at the light-green and yellowish-green stages, with $\mathrm{F}_{\mathrm{m}}$ and $\mathrm{F}_{\mathrm{v}}$ having the best correlations with skin color (figure 5b, 5c). Changes in skin color of guava fruit are directly associated with chlorophyll degradation [28], which affects the chlorophyll fluorescence emission. Hence, our results suggest a relationship between decreases in $\mathrm{F}_{\mathrm{m}}$ (figure $3 b$ ) and chlorophyll content, as evaluated by $\mathrm{H}^{\circ}$ (figure 4). This has also been verified in banana fruit, which had $\mathrm{F}_{\mathrm{m}}$ reduction associated with chlorophyll degradation [29].

Curiously, the correlations between $\left[\mathrm{F}_{\mathrm{v}}\right]$ $\mathrm{F}_{\mathrm{m}}$ ] and $\mathrm{H}^{\circ}$ decreased from stages I to III (figure $5 d$ ), whereas the correlations between $\mathrm{F}_{\mathrm{O}}, \mathrm{F}_{\mathrm{m}}, \mathrm{F}_{\mathrm{v}}$ and $\mathrm{H}^{\circ}$ increased (figures $5 a, 5 \mathrm{c}$ ). It is important to note that $\left[\mathrm{F}_{\mathrm{v}} / \mathrm{F}_{\mathrm{m}}\right]$ represents the efficiency of light energy transference and photosynthetic activity [21]. So, the low correlation between $\left[\mathrm{F}_{\mathrm{v}} / \mathrm{F}_{\mathrm{m}}\right]$ and $\mathrm{H}^{\circ}\left(r^{2}=\right.$ 0.518 ) at stage III reflected the high variability (given by data scattering) between chloroplast activity and chlorophyll content with advancing ripening of fruit harvested at stage III. Since the fruit ripeness stage at harvest influenced the chlorophyll fluorescence changes, care must be taken when considering the chlorophyll fluorescence parameter that best describes the changes in skin color during ripening of guava fruit.

The results of this study show that chlorophyll fluorescence can be used to evaluate the ripening and senescence of guava fruit, with $\mathrm{F}_{\mathrm{m}}$ being a good ripening parameter. This parameter accompanied skin color changes, improving the detection of initial ripening changes in guava fruit. As suggested by Bron et al. [3] in papaya fruit, chlorophyll 
fluorescence can represent a relevant tool to evaluate the ripening process when associated with other conventional measurements of fruit quality. However, this hypothesis must be tested in future studies.

\section{References}

[1] Tucker G.A., Introduction, In: Seymour G.B., Taylor J.E., Tucker G.A. (Eds.), Biochemistry of fruit ripening, Chapman \& Hall, London, UK, 1993.

[2] Abbott J.A., Quality measurement of fruits and vegetables, Postharvest Biol. Tec. 15 (1999) 207-225.

[3] Bron I.U., Ribeiro R.V., Azzolini M., Jacomino A.P., Machado E.C., Chlorophyll fluorescence as a tool to evaluate the ripening of 'Golden' papaya fruit, Postharvest Biol. Tec. 33 (2004) 163-173.

[4] Song F., Deng W., Beaudry R.M., Changes in chlorophyll fluorescence of apple fruit during maturation, ripening, and senescence, HortScience 32 (1997) 891-896.

[5] Mir N.A., Perez R., Beaudry R.M., Chlorophyll fluorescence and whole fruit senescence in 'Golden Delicious' apple, Acta Hortic. 464 (1998) 121-126.

[6] DeEll J.R., van Kooten O., Prange R.K., Murr D.P., Applications of chlorophyll fluorescence techniques in postharvest physiology, Hortic. Rev. 23 (1999) 69-107.

[7] DeEll J.R., Toivonen P.M.A., Chlorophyll fluorescence as a nondestructive indicator of broccoli quality during storage in modifiedatmosphere packaging, HortScience 35 (2000) 256-259.

[8] Smillie R.M., Hetherington S.E., Nott R., Chaplin G.R., Wade N.L., Application of chlorophyll fluorescence to the postharvest physiology and storage of mango and banana fruit and the chilling tolerance of mango cultivars, Asean Food J. 3 (1987) 55-59.

[9] DeEll J.R., Prange R.K., Murr D.P., Chlorophyll fluorescence techniques to detect atmospheric stress in stored apples, Acta Hortic. 464 (1998) 127-131.

[10] DeEll J.R., Prange R.K., Murr D.P., Chlorophyll fluorescence of Delicious apples at harvest as a potential predictor of superficial scald development during storage, Postharvest Biol. Tec. 9 (1996) 1-6.

[11] Mir N., Wendorf M., Perez R., Beaudry R.M., Chlorophyll fluorescence in relation to super-
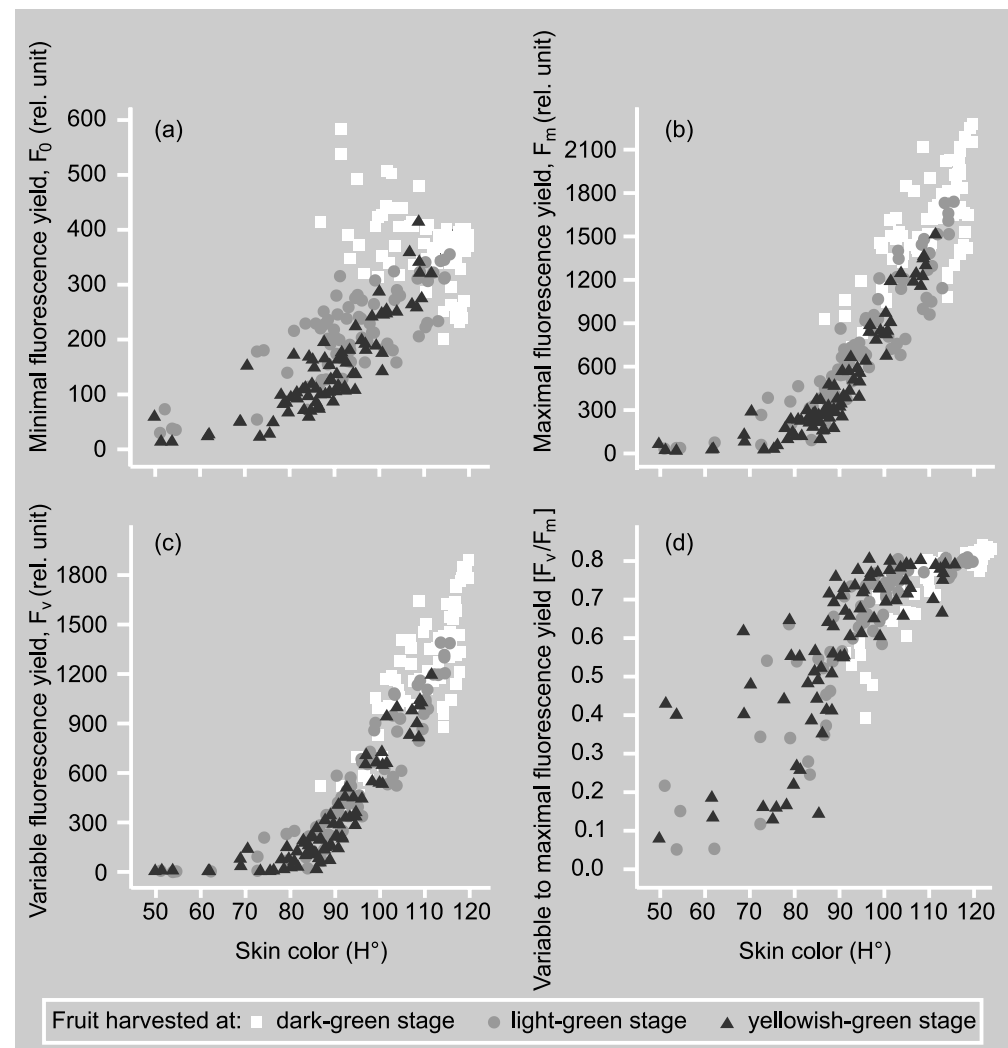

Fruit harvested at: dark-green stage light-green stage $\Delta$ yellowish-green stage

ficial scald development in apple, J. Am. Soc. Hortic. Sci. 123 (1998) 887-892.

[12] Schreiber U., Bilger W., Rapid assessment of stress effects on plant leaves by chlorophyll fluorescence measurements, in: Tenhunen J.D., Catarino F.M., Lange O.L., Oechel W.C. (Eds.), Plant response to stress - functional analysis in Mediterranean ecosystems, NATO Advanced Science Institute Series, Springer Verlag, Berlin, Germany, 1987.

[13] Krause G.H., Weis E., Chlorophyll fluorescence and photosynthesis: the basics, Annu. Rev. Plant Physiol. Plant Mol. Biol. 42 (1991) 313-349.

[14] Schreiber U., Bilger W., Neubauer C., Chlorophyll fluorescence as a non-intrusive indicator for rapid assessment of in vivo photosynthesis, in: Schulze E.D., Caldwell M.M. (Eds.), Ecophysiology of photosynthesis, Springer-Verlag, Berlim, Germany, 1994.

[15] Schreiber U., Bilger W., Hormann H., Neubauer C., Chlorophyll fluorescence as a diagnostic tool: basics and some aspects of practical relevance, in: Ragavendra A.S. (Ed.), Photosynthesis: a comprehensive treatise, Cambridge University Press, Cambridge, UK, 1998.

\section{Figure 5.}

Chlorophyll fluorescence parameters as a function of skin color during the ripening of guava fruit harvested at three ripeness stages: dark-green, light-green and yellowish-green. Guava fruits were held at room conditions $\left[(24 \pm 1)^{\circ} \mathrm{C}\right.$ and relative humidity of $(80 \pm 4) \%]$. Points represent all measurements taken during the ripening period (7 days).

(a) $r^{2}=-0.461,0.563$ and 0.810 for the dark-green, light-green and yellowish-green ripeness stages, respectively;

(b) $r^{2}=0.535,0.843$ and 0.923 for the dark-green, light-green and yellowish-green ripeness stages, respectively;

(c) $r^{2}=0.657,0.845$ and 0.893 for the dark-green, light-green and yellowish-green ripeness stages, respectively; (d) $r^{2}=0.862,0.760$ and 0.518 for the dark-green, light-green and yellowish-green ripeness stages, respectively. 
[16] Maxwell K., Johnson G.N., Chlorophyll fluorescence - a practical guide, J. Exp. Bot. 51 (2000) 659-668.

[17] Sanxter S.S., Yamamoto H.Y., Fisher D.G., Chan H.T., Development and decline of chloroplasts in exocarp of Carica papaya, Can. J. Bot. 70 (1992) 364-373.

[18] Marangoni A.G., Palma T., Stanley D.W., Membrane effects in postharvest physiology, Postharvest Biol. Tec. 7 (1996) 193-217.

[19] Gepstein S., Photosynthesis, in: Nooden L.D. Leopold A.C. (Eds.), Senescence and aging in plants, Academic Press, San Diego, USA, 1988.

[20] Choudhury M.M., Costa T.S., Araújo J.L.P., Agronegócio da goiaba, in: Choudhury M.M. (Ed.), Goiaba: pós-colheita, Embrapa Informação Tecnológica, Brasília, Brasil, 2001.

[21] Van Kooten O., Snel J.F.H., The use of chlorophyll fluorescence nomenclature in plant stress physiology, Photosynth. Res. 25 (1990) 147-150.

[22] Azzolini M., Jacomino A.P., Bron I.U., Índices para avaliar qualidade pós-colheita de goiabas em diferentes estádios de maturação, Pesqui. Agropecu. Bras. 39 (2004) 139-145.

[23] Huber J., The role of cell wall hydrolases in fruit softening, Hortic. Rev. 5 (1983) 169-219.

[24] Takamiya K., Tsuchiya T., Ohta H., Degradation pathway(s) of chlorophyll: what has gene cloning revealed? Trends Plant Sci. 5 (2000) 426-431.

[25] Kitao M., Lei T.T., Koike T., Tobita H., Maruyama Y., Matsumoto Y., Ang L., Temperature response and photoinhibition investigated by chlorophyll fluorescence measurements for four distinct species of dipterocarp trees, Physiol. Plantarum 109 (2000) 284-290.

[26] Krause G.H., Weis E., Chlorophyll fluorescence as a tool in plant physiology. II. Interpretation of fluorescence signals, Photosyn. Res. 5 (1984) 139-157.

[27] DeEll J.R., Prange R.K., Murr D.P., Chlorophyll fluorescence as an indicator of apple fruit firmness, in: Proc. Int. conference on sensors for nondestructive testing: measuring the quality of fresh fruits and vegetables, Natural Resource, Agriculture and Engineering Service, Orlando, USA, 1997, pp. 67-73.

[28] Jain N., Dhawan K., Malhotra S.P., Siddiqui S., Singh R., Compositional and enzymatic changes in guava (Psidium guajava L.) fruits during ripening, Acta Physiol. Plant. 23 (2001) 357-362.

[29] Blackbourn H.D., Jeger M.J., John P., Telfer A., Barber J., Inhibition of degreening in the peel of bananas ripened at tropical temperatures. IV. Photosynthetic capacity of ripening bananas and plantains in relation to changes in the lipid composition of ripening banana peel, Ann. Appl. Biol. 117 (1990) 163-174.

\section{Fluorescencia emitida por la clorofila en relación con el color de la piel y la firmeza del fruto durante la maduración de la guayaba.}

Resumen - Introducción. La fluorescencia de la clorofila (fluorescencia-chl) ha sido utilizada en estudios postcosecha como técnica no destructiva para evaluar la maduración del fruto. Al no existir estudios que utilicen la fluorescencia-chl en la guayaba, nuestro objetivo consistió en verificar las relaciones que unen la fluorescencia-chl y ciertos parámetros de calidad de la fruta, como el color de piel y la firmeza de fruta, y en medir la fluorescencia-chl durante la maduración de la guayaba. Material y métodos. Primero, se evaluaron los rendimientos de la fluorescencia máxima $\left(\mathrm{F}_{\mathrm{m}}\right)$, mínima $\left(\mathrm{F}_{\mathrm{o}}\right)$ y variable $\left(\mathrm{F}_{\mathrm{v}}\right)$, y la relación $\left[\mathrm{F}_{\mathrm{v}} / \mathrm{F}_{\mathrm{m}}\right]$, el color de piel $\left(\mathrm{H}^{\circ}\right)$ y la firmeza de fruta en guayabas cosechadas en tres estadios de madurez: (I) verde oscuro (II) verde claro y (III) verde amarillento. Posteriormente, se midieron los cambios de estos últimos parámetros de fluorescencia-chl y de $\mathrm{H}^{\circ}$ durante 7 días de maduración. También se analizaron las relaciones entre los parámetros evaluados. Resultados y discusión. Los tres estadios de madurez se pudieron discriminar bien utilizando los parámetros $\mathrm{H}^{\circ}, \mathrm{F}_{\mathrm{m}}$ y la firmeza de fruta. $\mathrm{F}_{\mathrm{O}}$ se mostró insensible a los primeros cambios de la maduración del fruto, manteniendo unos valores relativamente estables hasta que la firmeza del fruto llega a 20 N. No se observó ninguna diferencia significativa de fluorescencia-chl ni de $\mathrm{H}^{\circ}$ entre las guayabas cosechadas en los estadios II o III. El declive del valor $\left[\mathrm{F}_{\mathrm{v}} / \mathrm{F}_{\mathrm{m}}\right]$ sólo se evidenció a partir del quinto día de maduración, mientras que los parámetros $\mathrm{F}_{\mathrm{V}}$ $\mathrm{F}_{\mathrm{m}} \mathrm{y} \mathrm{H}^{\circ}$ empezaron a disminuir desde el primer día. Independientemente de la relación $\left[\mathrm{F}_{\mathrm{v}} / \mathrm{F}_{\mathrm{m}}\right]$, las relaciones entre los parámetros de fluorescencia-chl y $\mathrm{H}^{\circ}$ tendieron a aumentar del estadio de madurez I al estadio III; $\mathrm{F}_{\mathrm{m}}$ mostró la correlación más fuerte con $\mathrm{H}^{\circ}$. Los resultados ponen de manifiesto que la fluorescencia-chl puede ser empleada para evaluar la maduración y la senescencia de la guayaba al ser $\mathrm{F}_{\mathrm{m}}$ un buen indicador de maduración.

Brasil / Psidium guajava / fruto / maduramiento / metodos no destructivos / clorofilas / fluorescencia / firmeza / coloración 